\title{
Coupling Pre-Reforming and Partial Oxidation for LPG Conversion to Syngas
}

\author{
Dmitriy I. Potemkin 1,2,3,*(1), Vladimir N. Rogozhnikov ${ }^{3,4}$, Sergey I. Uskov ${ }^{2,3}$, \\ Vladislav A. Shilov 2,3, Pavel V. Snytnikov 2,3 (D) and Vladimir A. Sobyanin 2,3 \\ 1 Department of Environmental Engineering, Novosibirsk State Technical University, Karl Marx Pr., 20, \\ 630073 Novosibirsk, Russia \\ 2 Department of Natural Sciences, Novosibirsk State University, Pirogova St., 2, 630090 Novosibirsk, Russia; \\ serg5810@gmail.com (S.I.U.); dubbmx97@gmail.com (V.A.S.); pvsnyt@catalysis.ru (P.V.S.); \\ sobyanin@catalysis.ru (V.A.S.) \\ 3 Boreskov Institute of Catalysis, Pr. Lavrentieva, 5, 630090 Novosibirsk, Russia; rvn@catalysis.ru \\ 4 Faculty of Oil and Gas Field Development, Gubkin Russian State University of Oil and Gas, Leninsky Pr., 65, \\ 119991 Moscow, Russia \\ * Correspondence: potema@catalysis.ru; Tel.: +7-913-932-46-20
}

Received: 31 August 2020; Accepted: 18 September 2020; Published: 21 September 2020

\begin{abstract}
Coupling of the pre-reforming and partial oxidation was considered for the conversion of liquefied petroleum gas to syngas for the feeding applications of solid oxide fuel cells. Compared with conventional two step steam reforming, it allows the amount of water required for the process, and therefore the energy needed for water evaporation, to be lowered; substitution of high-potential heat by lower ones; and substitution of expensive tubular steam reforming reactors by adiabatic ones. The supposed process is more productive due to the high reaction rate of partial oxidation. The obtained syngas contains only ca. $10 \mathrm{vol} . \% \mathrm{H}_{2} \mathrm{O}$ and ca. $50 \mathrm{vol} \%$ of $\mathrm{H}_{2}+\mathrm{CO}$, which is attractive for the feeding application of solid oxide fuel cells. Compared with direct partial oxidation of liquefied petroleum gas, the suggested scheme is more energy efficient and overcomes problems with coke formation and catalyst overheating. The proof-of-concept experiments were carried out. The granular $\mathrm{Ni}-\mathrm{Cr}_{2} \mathrm{O}_{3}-\mathrm{Al}_{2} \mathrm{O}_{3}$ catalyst was shown to be effective for propane pre-reforming at $350-400{ }^{\circ} \mathrm{C}, \mathrm{H}_{2} \mathrm{O}: \mathrm{C}$ molar ratio of 1.0, and flow rate of $12,000 \mathrm{~h}^{-1}$. The composite $\mathrm{Rh} / \mathrm{Ce}_{0.75} \mathrm{Zr}_{0.25} \mathrm{O}_{2-\delta}-\eta-\mathrm{Al}_{2} \mathrm{O}_{3} / \mathrm{FeCrAl}$ catalyst was shown to be active and stable under conditions of partial oxidation of methane-rich syngas after pre-reforming and provided a syngas $\left(\mathrm{H}_{2}+\mathrm{CO}\right.$ ) productivity of $28 \mathrm{~m}^{3} \cdot \mathrm{L}_{\mathrm{cat}}{ }^{-1} \cdot \mathrm{h}^{-1}$ (standard temperature and pressure).
\end{abstract}

Keywords: syngas; pre-reforming; partial oxidation; tri-reforming; LPG; propane; SOFC

\section{Introduction}

The solid oxide fuel cell (SOFC) is an attractive device for direct conversion of chemical energy of fuel to electricity with additional heat production [1]. Due to its high working temperature, a SOFC can operate on both pure hydrogen and synthesis gas (syngas) [2] obtained from hydrocarbon fuels (methane, liquified petroleum gas (LPG), liquid hydrocarbons) by steam conversion [3], partial oxidation (PO) [4], dry reforming [5,6], or autothermal reforming [7]. In the case of a SOFC stack with power of several kilowatts or more, the heat released during the reaction can be efficiently utilized to conduct endothermal steam reforming of the initial fuel. This increases the efficiency of the entire system (reformer + SOFC system). For small power SOFCs, usually less than 1-2 kW, the heat generated 
is not always enough to simultaneously maintain the required stack temperature and for endothermic steam reforming. In this case, it is preferable to use an exothermic partial oxidation process:

$$
2 \mathrm{CH}_{4}+\mathrm{O}_{2} \rightarrow 2 \mathrm{CO}+4 \mathrm{H}_{2}\left(\Delta_{\mathrm{r}} \mathrm{H}_{973 \mathrm{~K}}^{0}=-46.4 \mathrm{~kJ} / \mathrm{mol}\right)
$$

However, the overall efficiency of the power plant is significantly reduced. In addition, when using LPG (which can be compactly stored in a liquid state in cylinders at low pressure) during partial oxidation, the conversion temperature usually exceeds $900^{\circ} \mathrm{C}$, which leads to accelerated degradation of the catalyst [8].

One of the options for increasing the efficiency of fuel conversion is a process that combines the weakly exothermic process of LPG pre-reforming at low temperatures and partial oxidation of the resulting methane-hydrogen mixture, the temperature of which is significantly lower than the temperature of LPG partial oxidation:

$$
4 \mathrm{C}_{\mathrm{n}} \mathrm{H}_{2 \mathrm{n}+2}+2(\mathrm{n}-1) \mathrm{H}_{2} \mathrm{O} \rightarrow(3 \mathrm{n}+1) \mathrm{CH}_{4}+(\mathrm{n}-1) \mathrm{CO}_{2}\left(\Delta_{\mathrm{r}} \mathrm{H}^{0}{ }_{673 \mathrm{~K}}=-80.8 \mathrm{~kJ} / \mathrm{mol} \text { for } \mathrm{n}=3\right)
$$

In addition, the pre-reforming process requires much smaller amounts of water to be supplied than for the classic steam reforming process [9].

In this work we considered the possibility of combining pre-reforming at a low steam to carbon ratio and subsequent partial oxidation to maximize the energy efficiency of syngas production from LPG and carried out proof-of-concept experiments.

\section{Results and Discussion}

Propane, the main component of LPG, was chosen as a model compound. In our previous work the $\mathrm{Ni}-\mathrm{Cr}_{2} \mathrm{O}_{3}-\mathrm{Al}_{2} \mathrm{O}_{3}$ catalyst was shown to be effective in propane pre-reforming [10]. As an example, Figure 1 shows the temperature dependences of the outlet concentrations of propane, methane, carbon dioxide, and hydrogen during propane pre-reforming under 1 bar pressure, with a $\mathrm{H}_{2} \mathrm{O}: \mathrm{C}$ molar ratio of 1.0 and gas hourly space velocity (GHSV) of $12,000 \mathrm{~h}^{-1}$. It is seen that the propane conversion and $\mathrm{CH}_{4}, \mathrm{H}_{2}$ and $\mathrm{CO}_{2}$ concentrations increased with the increase of temperature, reaching equilibrium values at $380{ }^{\circ} \mathrm{C}$.

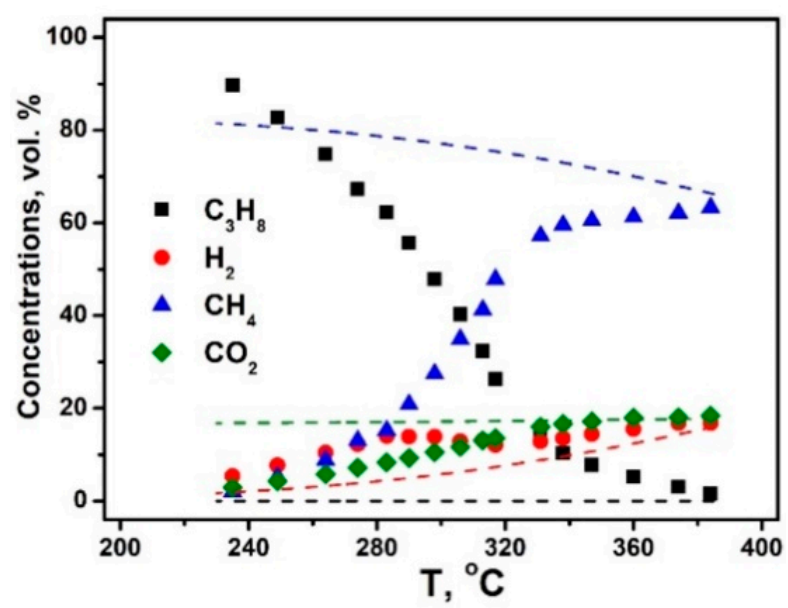

Figure 1. The outlet concentrations of propane, methane, carbon dioxide, and hydrogen (on the dry basis) as a function of temperature during propane pre-reforming. Experimental conditions: 240-400 ${ }^{\circ} \mathrm{C}$, GHSV 12,000 $\mathrm{h}^{-1}, 1$ bar pressure, reaction mixture: 25 vol. $\% \mathrm{C}_{3} \mathrm{H}_{8}, 75$ vol. $\% \mathrm{H}_{2} \mathrm{O}$. Points are experimental. Dashed lines are equilibrium concentrations.

Methane-rich gas (MRG) after pre-reforming typically contains $40-70$ vol. $\% \mathrm{CH}_{4}, 10-30$ vol.\% $\mathrm{H}_{2} \mathrm{O}, 5-15$ vol. $\% \mathrm{CO}_{2}, 5-20$ vol. $\% \mathrm{H}_{2}$, and $0.1-2$ vol.\% CO. The obtained methane-rich gas can be 
converted to syngas via the addition of the required quantity of oxygen or air. As the resulting mixture will contain water steam together with oxygen, the process will be near autothermal, which is especially convenient for compact systems.

It was previously demonstrated $[8,11]$ that $\mathrm{Rh} / \mathrm{Ce}_{0.75} \mathrm{Zr}_{0.25} \mathrm{O}_{2-\delta}-\eta-\mathrm{Al}_{2} \mathrm{O}_{3} / \mathrm{FeCrAl}$ catalyst (further Rh-block) was highly efficient in the autothermal reforming of diesel fuel, exhibiting high catalytic activity, stability, and a low tendency to carbonization. In this work, its properties in the partial oxidation of methane-rich gas are studied.

Figure 2 shows the dependences of the outlet concentrations of $\mathrm{H}_{2}, \mathrm{~N}_{2}, \mathrm{CO}, \mathrm{CO}_{2}$, and $\mathrm{CH}_{4}$ and the temperatures at the inlet $\left(\mathrm{T}_{\text {in }}\right)$ and outlet $\left(\mathrm{T}_{\text {out }}\right)$ centerline points of the catalytic block as a function of the flow rate of the reaction mixture (GHSV) for the PO of MRG over the Rh-block at $730{ }^{\circ} \mathrm{C}$. It is seen that, for all flows, the distribution of products was close to equilibrium at $700{ }^{\circ} \mathrm{C}$. The temperature at the outlet of the block varied from 693 to $730^{\circ} \mathrm{C}$, i.e., was close to $700^{\circ} \mathrm{C}$, which explains the closeness of the product distribution to equilibrium. However slight increase of $\mathrm{CH}_{4}$ outlet concentration, accompanied with the decrease of $\mathrm{H}_{2}$ and CO level, was observed at GHSVs $40,000-60,000 \mathrm{~h}^{-1}$, indicating the limitation of the overall reaction rate.

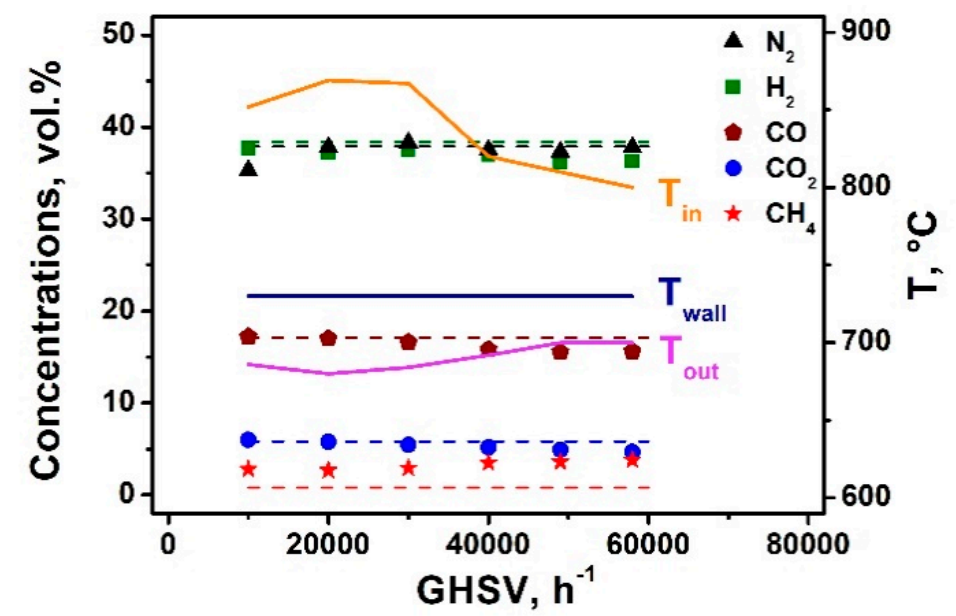

Figure 2. The inlet $\left(\mathrm{T}_{\mathrm{in}}\right)$ and outlet $\left(\mathrm{T}_{\text {out }}\right)$ temperatures of the Rh-block, $\mathrm{H}_{2}, \mathrm{~N}_{2}, \mathrm{CO}, \mathrm{CO}_{2}$, and $\mathrm{CH}_{4}$ concentrations (on a dry basis) as a function of space velocity (GHSV) for partial oxidation (PO) of methane-rich gas (MRG). Experimental conditions: GHSV 18,000-55,000 $\mathrm{h}^{-1}, 1$ bar pressure, reactor wall temperature $730{ }^{\circ} \mathrm{C}$, reaction mixture (vol.\%): $25.6 \mathrm{CH}_{4}, 13.4 \mathrm{O}_{2}, 10.5 \mathrm{H}_{2} \mathrm{O}$, and $50.5 \mathrm{~N}_{2}$. Points are experimental. Dashed lines are equilibrium concentrations.

The temperature at the catalyst inlet exceeded the reactor wall temperature $\left(730^{\circ} \mathrm{C}\right)$ and the outlet temperature, which was associated with the exothermic reaction of complete oxidation of methane and hydrogen. The outlet temperature, on the contrary, did not exceed the temperature of the walls of the reactor, which was due to the endothermic reactions of steam and dry reforming of methane. In this case, with an increase in the flow rate, $T_{\text {in }}$ decreased and $\mathrm{T}_{\text {out }}$ increased. This is apparently associated with an increase in the heat release rate on the catalyst and with the stretching of the zone in which complete oxidation of methane and hydrogen occurs, with an increase of GHSV, which is caused by external diffusion limitation of the rate of total oxidation [12].

The stability of catalytic properties was studied during $25 \mathrm{~h}$ on stream. The test was performed at a reactor wall temperature of $730^{\circ} \mathrm{C}$ and GHSV of $20,000 \mathrm{~h}^{-1}$ and the following reaction mixture (vol.\%): $25.6 \mathrm{CH}_{4}, 13.4 \mathrm{O}_{2}, 10.5 \mathrm{H}_{2} \mathrm{O}$, and $50.5 \mathrm{~N}_{2}$. The GHSV was periodically raised to $55,000 \mathrm{~h}^{-1}$ (Figure 3a) to check the catalyst activity in the conditions at which the reaction was under kinetic control (product distribution differs from the equilibrium). The properties of the catalyst were constant during $25 \mathrm{~h}$ on stream (Figure $3 \mathrm{~b}$ ). The weight of the block did not change after the experiment; no damage (detachments) of the catalytic coating was detected. No carbon deposits were detected by 
temperature-programmed oxidation. Thus, the Rh-block showed stable operation under PO MRG conditions and provided a syngas $\left(\mathrm{H}_{2}+\mathrm{CO}\right)$ productivity of $28 \mathrm{~m}^{3} \cdot \mathrm{L}_{\mathrm{cat}}{ }^{-1} \cdot \mathrm{h}^{-1}(\mathrm{STP})$.
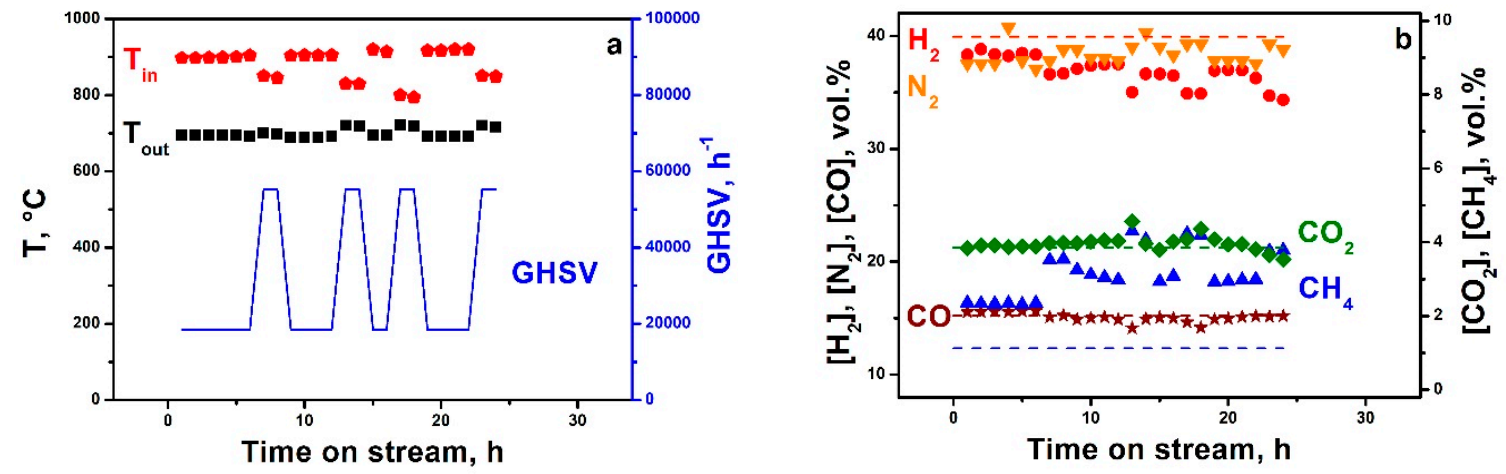

Figure 3. The inlet $\left(\mathrm{T}_{\mathrm{in}}\right)$ and outlet $\left(\mathrm{T}_{\mathrm{out}}\right)$ temperatures of the Rh-block and space velocity $(\mathbf{a}) ; \mathrm{H}_{2}$, $\mathrm{N}_{2}, \mathrm{CO}, \mathrm{CO}_{2}$, and $\mathrm{CH}_{4}$ concentrations (b) (on a dry basis) as a function of time on stream for PO of methane-rich syngas. Experimental conditions: GHSV $18,000-55,000 \mathrm{~h}^{-1}, 1$ bar pressure, reactor wall temperature $730{ }^{\circ} \mathrm{C}$, reaction mixture (vol.\%): $25.6 \mathrm{CH}_{4}, 13.4 \mathrm{O}_{2}, 10.5 \mathrm{H}_{2} \mathrm{O}$, and $50.5 \mathrm{~N}_{2}$. Points are experimental. Dashed lines are equilibrium concentrations.

We also studied the light-on curve for the Rh-block in PO MRG, as it is important to determine the minimal outlet temperature after pre-reforming at which the PO could be launched. Figure 4 shows the dependence of the temperatures at the inlet $\left(\mathrm{T}_{\text {in }}\right)$ and outlet $\left(\mathrm{T}_{\text {out }}\right)$ centerline points of the catalytic block and the outlet concentrations of $\mathrm{H}_{2}, \mathrm{~N}_{2}, \mathrm{CO}, \mathrm{CO}_{2}$, and $\mathrm{CH}_{4}$ as a function of the reactor wall temperature. It is seen that at the initial temperature of $350{ }^{\circ} \mathrm{C}, \mathrm{T}_{\text {in }}$ and $\mathrm{T}_{\text {out }}$ were similar to $\mathrm{T}_{\text {wall }}$, indicating the absence of a PO reaction. A $\mathrm{T}_{\text {wall }}$ increase to $400{ }^{\circ} \mathrm{C}$ induced a sharp rise of $\mathrm{T}_{\text {in }}$ and $\mathrm{T}_{\text {out }}$ to 598 and $465{ }^{\circ} \mathrm{C}$, respectively. Thus, the temperature of $400^{\circ} \mathrm{C}$ could be considered as a light-on one. Further increases of $\mathrm{T}_{\text {wall }}$ provided a gradual increase of $\mathrm{T}_{\text {in }}, \mathrm{T}_{\text {out }}$, and progress of the reaction. Product distribution at $600-730^{\circ} \mathrm{C}$ was close to equilibrium. Rapid product composition changes at $400-600^{\circ} \mathrm{C}$ were difficult to register by gas chromatography. Transient switch on/off regimes will be the subject of further studies.

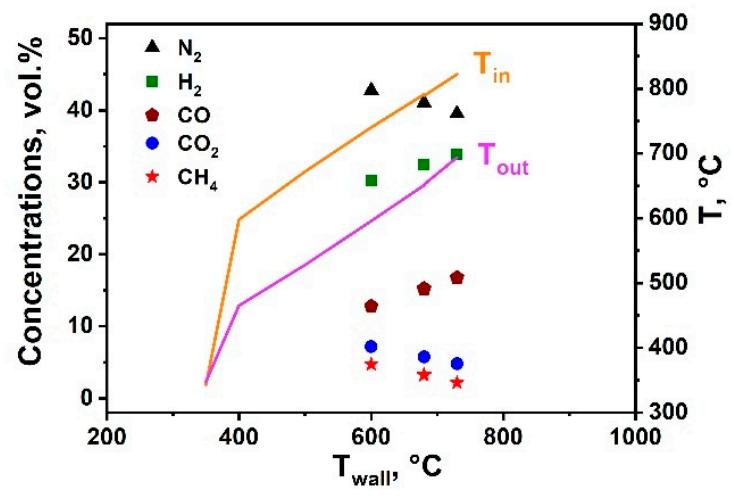

Figure 4. The inlet $\left(\mathrm{T}_{\mathrm{in}}\right)$ and outlet $\left(\mathrm{T}_{\mathrm{out}}\right)$ temperatures of the Rh-block and $\mathrm{H}_{2}, \mathrm{~N}_{2}, \mathrm{CO}, \mathrm{CO}_{2}$, and $\mathrm{CH}_{4}$ concentrations (on a dry basis) as a function of reactor wall temperature $\left(\mathrm{T}_{\text {wall }}\right)$ for PO of MRG. Experimental conditions: GHSV $11,000 \mathrm{~h}^{-1}, 1$ bar pressure, reaction mixture (vol.\%): $21.5 \mathrm{CH}_{4}, 11.3 \mathrm{O}_{2}$, $8.8 \mathrm{H}_{2} \mathrm{O}, 5 \mathrm{CO}_{2}$, and $53.4 \mathrm{~N}_{2}$.

Coupling pre-reforming and partial oxidation of the following syngas production scheme could be supposed (Figure 5): after mixing and heating the mixture of LPG and water steam $\left(\mathrm{H}_{2} \mathrm{O}: \mathrm{C}=1\right.$, molar) was supplied to the adiabatic pre-reformer at $400^{\circ} \mathrm{C}$; the outlet temperature of methane-rich gas (MRG) was $410^{\circ} \mathrm{C}$; heated air was mixed with MRG and supplied to the adiabatic partial oxidation reactor at 
$410{ }^{\circ} \mathrm{C}$; the resulted syngas with temperature of $670{ }^{\circ} \mathrm{C}$ was supplied directly to SOFC. The obtained syngas contained (vol.\%) $1.1 \mathrm{CH}_{4}, 36.4 \mathrm{H}_{2}, 13.1 \mathrm{CO}, 10.7 \mathrm{H}_{2} \mathrm{O}, 7.1 \mathrm{CO}_{2}, 0.4 \mathrm{Ar}$, and $31.2 \mathrm{~N}_{2}$ and could be successfully used for SOFC feeding. For $2 \mathrm{~kW}_{\mathrm{e}}$ SOFC only $0.2 \mathrm{Nm}^{3} / \mathrm{h} \mathrm{LPG}\left(80 \mathrm{~mol} . \% \mathrm{C}_{3} \mathrm{H}_{8}\right.$ and $20 \mathrm{~mol} \%$ $\mathrm{C}_{4} \mathrm{H}_{10}$ ) was required due to the high energy density of LPG. Furthermore, only $0.75 \mathrm{~kW}$ of heat power was required for water evaporation and gas superheating. Instead of the conventional steam reforming process, the heat in this scheme had low- and medium-potential: the maximal temperature had to be reached at $410{ }^{\circ} \mathrm{C}$. Thus, the process needs could be satisfied by SOFC heat output (ca. $0.5 \mathrm{~kW}$ for $2 \mathrm{~kW}_{\mathrm{e}} \mathrm{SOFC}$ ) and anode gases afterburning (ca. $0.4 \mathrm{~kW}$ ).

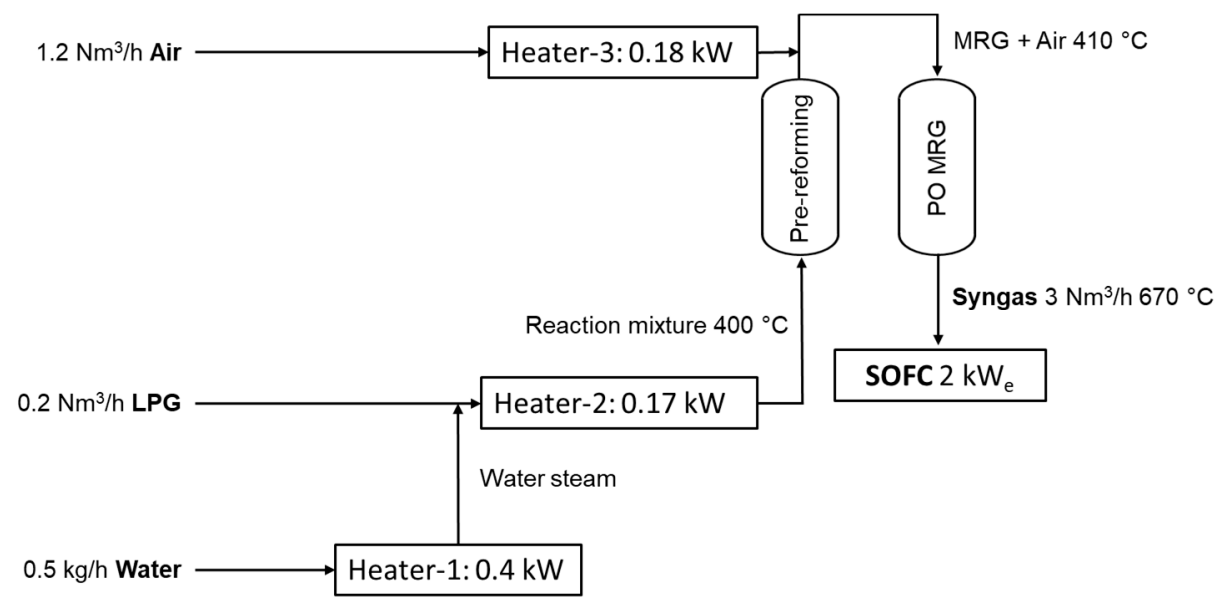

Figure 5. General scheme for the process of liquified petroleum gas (LPG) conversion to syngas for Figure 2. $\mathrm{kW}_{\mathrm{e}}$ solid oxide fuel cell (SOFC).

\section{Conclusions}

Compared with conventional two step steam reforming, coupling the pre-reforming and partial oxidation provides the reduction of amount of the water required for the process and therefore energy needed for its evaporation, substitution of high-potential heat by lower ones and expensive tubular steam reforming reactor by adiabatic one. In addition, the supposed process is more productive due to the high reaction rate of partial oxidation. The obtained syngas contains only ca. 10 vol. $\% \mathrm{H}_{2} \mathrm{O}$ and ca. 50 vol. $\%$ of $\mathrm{H}_{2}+\mathrm{CO}$ which is attractive for SOFC feeding application. Compared with direct partial oxidation of LPG, the suggested scheme is more energy efficient and overcomes problems with coke formation and catalyst overheating.

\section{Materials and Methods}

Propane pre-reforming was studied using NIAP-07-05 industrial catalyst (wt.\%): $42 \mathrm{NiO}, 12 \mathrm{Cr}_{2} \mathrm{O}_{3}$, $46 \mathrm{Al}_{2} \mathrm{O}_{3}$, and 4 graphite (NIAP Ltd., Novomoskovsk, Russia). This catalyst demonstrated high activity in the low-temperature steam conversion of light hydrocarbons in methane excess $[9,10]$.

The experiments on propane pre-reforming were carried out in a fixed-bed U-shaped quartz reactor (internal diameter $8 \mathrm{~mm}$, catalyst bed volume $1.7 \mathrm{~cm}^{3}$ ). Experimental conditions were as follows: 1 bar pressure, temperature of $240-400{ }^{\circ} \mathrm{C}$, GHSV of $12,000 \mathrm{~h}^{-1}$. Before the experiment, $2 \mathrm{~g}$ of the catalyst (fraction $0.5-1 \mathrm{~mm}$ ) were reduced at $420{ }^{\circ} \mathrm{C}$ in a flow of $10 \mathrm{~mL} / \mathrm{min}_{2}$ and $100 \mathrm{~mL} / \mathrm{min}$ Ar. The composition of the initial reaction mixture was 25 vol. $\% \mathrm{C}_{3} \mathrm{H}_{8}$ and 75 vol. $\% \mathrm{H}_{2} \mathrm{O}$, which corresponded to an $\mathrm{H}_{2} \mathrm{O} / \mathrm{C}$ molar ratio of 1 . The temperature of the catalyst was measured using a K-type thermocouple placed in the center of the catalyst bed. The composition of the gas phase components were determined using a Chromos GC-1000 chromatograph (CHROMOS Engineering company, Moscow, Russia). The concentration of carbon monoxide was negligible (below 0.1 vol.\%), and therefore $\mathrm{CO}$ was not taken into account when processing the results. The carbon imbalance in all the experiments did not exceed \pm 1 rel.\%. 
The composite $\mathrm{Rh} / \mathrm{Ce}_{0.75} \mathrm{Zr}_{0.25} \mathrm{O}_{2-\delta}-\eta-\mathrm{Al}_{2} \mathrm{O}_{3} / \mathrm{FeCrAl}$ (Rh-block) was prepared according to [8]. The cylindric Rh-block was $60 \mathrm{~mm}$ long and $18 \mathrm{~mm}$ in diameter. The weight of the Rh-block was $13.7 \mathrm{~g}$, Total weight of the $\mathrm{Rh} / \mathrm{Ce}_{0.75} \mathrm{Zr}_{0.25} \mathrm{O}_{2-\delta}-\eta-\mathrm{Al}_{2} \mathrm{O}_{3}$ coating was $1.58 \mathrm{~g}$.

Partial oxidation of methane-rich gas over the $\mathrm{Rh} / \mathrm{Ce}_{0.75} \mathrm{Zr}_{0.25} \mathrm{O}_{2-\delta}-\eta-\mathrm{Al}_{2} \mathrm{O}_{3} / \mathrm{FeCrAl}$ catalyst was studied in a stainless steel flow reactor under atmospheric pressure. The catalyst was preliminarily reduced in a flow of $5 \mathrm{vol} . \% \mathrm{H}_{2} / \mathrm{N}_{2}$ at $600{ }^{\circ} \mathrm{C}$ for $1 \mathrm{~h}$. Afterwards, the reaction mixture was fed into the reactor. The volumetric flow rate of the mixture was varied in the range $10,000-55,000 \mathrm{~h}^{-1}$. The temperature at the inlet and outlet of the block was measured with thermocouples along the central axis of the block. The composition of the gas phase components of the reaction mixture was determined using a Chromos GC-1000 (CHROMOS Engineering company, Moscow, Russia) gas chromatograph equipped with a thermal conductivity detector (TCD) and a flame ionization detector (FID) with a methanator. Before analysis, water was removed from the reformate using a moisture trap. Concentrations of $\mathrm{H}_{2}$ and $\mathrm{N}_{2}$ separated in a CaA column with an $\mathrm{Ar}$ carrier gas were determined with TCD. The $\mathrm{CO}, \mathrm{CO}_{2}$, and $\mathrm{CH}_{4}$ were separated in a Chromosorb 106 column and quantified using FID. The "blank" experiment without a catalyst showed that at the used volumetric flow rates, the reaction on the walls of the reactor was not significant and could be ignored when analyzing the results.

Equilibrium concentrations were calculated using the HSC Chemistry 7.1 software package (HSC Chemistry, version 7.1, Outotec (company), 2011) under the assumption that the equilibrium mixture contains only gaseous substances.

Author Contributions: Conceptualization, D.I.P.; methodology, D.I.P.; software, validation, P.V.S.; formal analysis, investigation, D.I.P., S.I.U., V.A.S. (Vladislav A. Shilov), V.N.R.; resources, data curation, writing-original draft preparation, D.I.P.; supervision, V.A.S. (Vladimir A. Sobyanin). All authors have read and agreed to the published version of the manuscript.

Funding: The work is supported by the Russian Foundation for Basic Research under the project 19-33-60008 "Perspectiva".

Conflicts of Interest: The authors declare no conflict of interest.

\section{References}

1. Ormerod, R.M. Solid oxide fuel cells. Chem. Soc. Rev. 2003, 32, 17-28. [CrossRef] [PubMed]

2. Amiri, A.; Tang, S.; Steinberger-Wilckens, R.; Tadé, M.O. Evaluation of fuel diversity in Solid Oxide Fuel Cell system. Int. J. Hydrog. Energy 2018, 43, 23475-23487. [CrossRef]

3. Abatzoglou, N.; Fauteux-Lefebvre, C. Review of catalytic syngas production through steam or dry reforming and partial oxidation of studied liquid compounds. Wiley Interdiscip. Rev. Energy Environ. 2016, 5, 169-187. [CrossRef]

4. Choudhary, T.V.; Choudhary, V.R. Energy-Efficient Syngas Production through Catalytic Oxy-Methane Reforming Reactions. Angew. Chemie Int. Ed. 2008, 47, 1828-1847. [CrossRef] [PubMed]

5. Sudhakaran, M.S.P.; Hossain, M.; Gnanasekaran, G.; Mok, Y. Dry Reforming of Propane over $\gamma$-Al2O3 and Nickel Foam Supported Novel SrNiO3 Perovskite Catalyst. Catalysts 2019, 9, 68. [CrossRef]

6. Råberg, L.B.; Jensen, M.B.; Olsbye, U.; Daniel, C.; Haag, S.; Mirodatos, C.; Sjåstad, A.O. Propane dry reforming to synthesis gas over Ni-based catalysts: Influence of support and operating parameters on catalyst activity and stability. J. Catal. 2007, 249, 250-260. [CrossRef]

7. Shoynkhorova, T.B.; Rogozhnikov, V.N.; Simonov, P.A.; Snytnikov, P.V.; Salanov, A.N.; Kulikov, A.V.; Gerasimov, E.Y.; Belyaev, V.D.; Potemkin, D.I.; Sobyanin, V.A. Highly dispersed $\mathrm{Rh} / \mathrm{Ce} 0.75 \mathrm{Zr} 0.25 \mathrm{O} 2-\delta-\eta-\mathrm{Al} 2 \mathrm{O} 3 / \mathrm{FeCrAl}$ wire mesh catalyst for autothermal $\mathrm{n}$-hexadecane reforming. Mater. Lett. 2018, 214, 290-292. [CrossRef]

8. Shoynkhorova, T.B.; Rogozhnikov, V.N.; Ruban, N.V.; Shilov, V.A.; Potemkin, D.I.; Simonov, P.A.; Belyaev, V.D.; Snytnikov, P.V.; Sobyanin, V.A. Composite Rh/Zr0.25Ce0.75O2- $\Delta-\eta-\mathrm{Al} 2 \mathrm{O} 3 / \mathrm{Fecralloy}$ wire mesh honeycomb module for natural gas, LPG and diesel catalytic conversion to syngas. Int. J. Hydrog. Energy 2019, 44, 9941-9948. [CrossRef]

9. Uskov, S.I.; Potemkin, D.I.; Shigarov, A.B.; Snytnikov, P.V.; Kirillov, V.A.; Sobyanin, V.A. Low-temperature steam conversion of flare gases for various applications. Chem. Eng. J. 2019, 368, 533-540. [CrossRef] 
10. Uskov, S.I.; Potemkin, D.I.; Enikeeva, L.V.; Snytnikov, P.V.; Gubaydullin, I.M.; Sobyanin, V.A. Propane Pre-Reforming into Methane-Rich Gas over Ni Catalyst: Experiment and Kinetics Elucidation via Genetic Algorithm. Energies 2020, 13, 3393. [CrossRef]

11. Shoynkhorova, T.B.; Simonov, P.A.; Potemkin, D.I.; Snytnikov, P.V.; Belyaev, V.D. Applied Catalysis B: Environmental sorption-hydrolytic deposition for diesel fuel reforming to syngas. Appl. Catal. B Environ. 2018, 237, 237-244. [CrossRef]

12. Kirillov, V.A.; Shigarov, A.B.; Kuzin, N.A.; Kireenkov, V.V.; Brayko, A.S.; Burtsev, N.V. Ni/MgO Catalysts on Structured Metal Supports for the Air Conversion of Low Alkanes into Synthesis Gas. Catal. Ind. 2020, 12, 66-76. [CrossRef] article distributed under the terms and conditions of the Creative Commons Attribution (CC BY) license (http://creativecommons.org/licenses/by/4.0/). 